\title{
PERILAKU PASIEN HIPERTENSI DALAM PENCEGAHAN KOMPLIKASI DI DESA SAMATAN WILAYAH KERJA PUSKESMAS PROPPO PAMEKASAN
}

\author{
Moh riski kurniawan, Rumah Sakit Larasati Kabupaten Pamekasan \\ e-mail:Rizkikiki088@gmail.com
}

\begin{abstract}
ABSTRAK
Terjadinya komplikasi hipertensi dikarenakan perilaku pasien hipertensi dalam bersikap tidak sesuai dengan anjuran diet hipertensi, makan makanan berkolesterol dan berlemak, sering konsumsi rokok serta kurang minatnya pasien hipertensi dalam menggali informasi tentang penyakit hipertensi. Tujuan penelitian ini adalah untuk mengetahui perilaku pasien hipertensi

Desain penelitian yang di gunakan adalah deskriptif. Populasi dan sampel adalah semua pasien hipertensi di Desa Samatan Wilayah Kerja Puskesmas Proppo Kabupaten Pamekasan yaitu sebanyak 44 orang dengan teknik sampling yang di gunakan Probability tipe random sampling. Alat ukur yang di gunakan ceklis wawancara, Pengolahan data melalui proses Editing, Coding, Scoring dan Tabulating dengan analis deskriptif (persentase) dan hasilnya bentuk tabel dan narasi

Berdasarkan hasil penelitian ini di dapatkan bahwa sebagian besar $(57 \%)$ responden perilaku pencegahan komplikasi kurang sebanyak 25 responden dan sebagian kecil (11\%) responden perilaku baik pencegahan komplikasi sebanyak 5 responden

Perilaku pasien hipertensi di pengaruhi oleh kurangnya peran aktif perawat atau petugas kesehatan sebagai pendidik dengan memberikan HE untuk meningkatkan perilaku yang lebih baik dan sehat.
\end{abstract}

Kata kunci: Perilaku, Pencegahan Komplikasi, Hipertensi

\section{PENDAHULUAN}

Hipertensi yaitu kumpulan gejala dari jantung dan pembuluh darah yang progresif, yang diakibatkan oleh kondisi lain yang lengkap dan berhubungan (Umar, 2012). Hipertensi merupakan penyakit yang sering terjadi di masyarakat, sering kali tidak disadari adanya tanda-tanda awal yang hanya berupa pusing, mata berkunang-kunang, cepat marah, rasa berat ditengkuk dan juga sulit tidur.

Berdasarkan data Riskesdas 2013 menyatakan bahwa prevalensi hipertensi di Indonesia mencapai 25,8\% berdasarkan umur $\geq 18$ Tahun sedangkan prevalensi hipertensi di Jawa Timur Tahun 2013 mencapai 26,4\%. Dari studi pendahuluan yang dilakukan oleh peneliti pada tanggal 20 April 2017 di Puskesmas Proppo Pamekasan di peroleh data tahun 2013 sebanyak 411 orang, tahun 2014 sebanyak 395 orang, pada tahun 2015 sebanyak 362 orang dan di desa Samatan jumlah Pasien yang mengalami hipertensi sebanyak 50 orang (Pembukuan Puskesmas Proppo). Hal ini menunjukkan tingginya kejadian hipertensi di masyarakat, Dan data yang terjadi komplikasi pada gagal jantung sebanyak 5 orang, sementara komplikasi terjadi stroke 4 orang dan gagal ginjal sebanyak 2 orang.

Gaya hidup yang bersifat negatif dapat menyebabkan hipertensi seperti kurang olah raga, berat badan berlebih, pola makan, genetik, merokok serta stres yang berlebihan. konsumsi makanan cepat saji, gorengan dan makanan yang diawetkan dengan garam dapur serta bumbu penyedap dalam jumlah tinggi. Terjadinya komplikasi hipertensi dikarenakan perilaku pasien hipertensi dalam bersikap tidak sesuai dengan anjuran diet hipertensi, makan makanan berkolesterol dan berlemak, sering konsumsi rokok serta kurang minatnya pasien hipertensi dalam menggali informasi tentang penyakit hipertensi. (Arjatmo, 2005).

Sedangkan pada petugas kesehatan diharapkan untuk selalu memberikan konseling (Penyuluhan) yang terbaik bagi para pasien hipertensi agar selalu patuh pada diet hipertensi serta lebih banyak aktifitas terutama olah raga, selain itu juga lebih teratur dalam memberikan konseling untuk selalu memberikan pengobatan pada pasien 
hipertensi baik secara farmakologi maupun dengan non farmakologi.

\section{METODE PENELITIAN}

Pada penelitian ini digunakan rancangan penelitian deskriptif, Populasi Seluruh penderita hipertensi Di Desa Tanjung wilayah kerja Puskesmas Proppojumlah N=50orang, Sampel Semua penderita hipertensi di Desa tanjung wilayah kerja Puskesmas Proppo sebanyak $\mathrm{n}=44$ orang. Alat yang digunakan dalam pengumpulan data yang dilaksanakan dalam penelitian ini adalah wawancara yang diserahkan pada responden untuk memenuhi data umum dan data khusus sebanyak 10 pernyataan

\section{HASIL PENELITIAN}

\section{Data Umum}

\subsection{Karakteristik Responden Berdasarkan Jenis Kelamin}

Tabel 1.1 Distribusi Frekuensi Responden Berdasarkan Jenis Kelamin di Desa Samatan Wilayah Kerja Puskesmas Proppo Kabupaten Pamekasan Tahun 2017.

\begin{tabular}{cccc}
\hline No & Jenis Kelamin & $\mathrm{f}$ & $\%$ \\
\hline 1. & Laki- Laki & 30 & 68 \\
2. & Perempuan & 14 & 32 \\
\hline & Total & 44 & 100 \\
\hline
\end{tabular}

Berdasarkan tabel 1.1 diketahui bahwa sebagian besar (68\%)responden Laki- laki sebanyak 30 responden dan hampir setengahnya $(32 \%)$ responden Perempuan sebanyak 14 responden.

2. Karakteristik Responden Berdasarkan Usia

Tabel 1.2 Distribusi Frekuensi Responden Berdasarkan Usia di Desa Samatan Wilayah Kerja Puskesmas Proppo Kabupaten Pamekasan Tahun 2017.

\begin{tabular}{cccc}
\hline No & Usia & f) & $(\%)$ \\
\hline 1. & 31- 50 Tahun & 20 & 46 \\
2. & 51-60 Tahun & 15 & 34 \\
3. & $\geq 60$ Tahun & 9 & 20 \\
\hline & Total & 44 & 100
\end{tabular}

Berdasarkan tabel 1.2 diketahui bahwa hampir setengah (46\%)responden berusia 31- 50 Tahun. sebanyak 20 responden dan sebagian kecil $(20 \%)$ responden berusia $\geq 61$ Tahun sebanyak 9 responden.

\subsection{Karakteristik Responden Berdasarkan Pendidikan}

Tabel 1.3 Distribusi Frekuensi Responden Berdasarkan Pendidikan di Desa Samatan Wilayah Kerja Puskesmas Proppo Kabupaten Pamekasan Tahun 2017.

\begin{tabular}{cccc}
\hline No & Pendidikan & F & $\%$ \\
\hline 1. & Putus Sekolah & 6 & 14 \\
2. & SD & 12 & 27 \\
3. & SMP & 14 & 32 \\
4. & SMA & 9 & 20 \\
5. & PT & 3 & 7 \\
\hline & Total & 44 & 100 \\
\hline
\end{tabular}

Berdasarkan tabel 1.3 diketahui bahwa hampir setengah (32\%)responden berpendidikan SMP sebanyak 14 responden dan sebagian kecil (7\%) responden berpendidikan Perguruan Tinggi sebanyak 3 responden.

\subsection{Karakteristik Responden Berdasarkan Pekerjaan}

Tabel 1.4 Distribusi Frekuensi Responden Berdasarkan Pekerjaan di Desa Samatan Wilayah Kerja Puskesmas Proppo Kabupaten Pamekasan Tahun 2017.

\begin{tabular}{cccc}
\hline No & Pekerjaan & F & $\%$ \\
\hline 1. & PNS & 3 & 7 \\
2. & Wiraswasta & 15 & 34 \\
3. & Petani & 24 & 54 \\
4. & Nelayan & 0 & 0 \\
5. & Tidak Bekerja & 2 & 4 \\
\hline & Total & 44 & 100 \\
\hline
\end{tabular}

Berdasarkan tabel 1.4 diketahui bahwa sebagian besar (54\%)responden bekerja sebagai Petani sebanyak 24 responden dan sebagian kecil (4\%) responden bekerja sebagai Tidak Bekerja sebanyak 2 responden.

\subsection{Karakteristik Responden Berdasarkan Perolehan Informasi}

Tabel 1.5 Distribusi Frekuensi Responden Berdasarkan Perolehan Informasi di Desa Samatan Wilayah Kerja Puskesmas Proppo Kabupaten Pamekasan Tahun 2017.

\begin{tabular}{cccc}
\hline No & Perolehan Informasi & f & $\%$ \\
\hline 1. & Media Massa & 9 & 20 \\
2. & Orang lain & 32 & 73 \\
3. & Petugas Kesehatan & 3 & 7 \\
\hline & Total & 44 & 100 \\
\hline
\end{tabular}

Berdasarkan tabel 1.5 diketahui bahwa sebagian besar (73\%)responden memperoleh 
informasi dari orang lain sebanyak 32 responden dan sebagian kecil $(7 \%)$ responden memperoleh informasi dari petugas kesehatan sebanyak 3 responden.

\section{DATA KHUSUS}

\subsection{Karakteristik Responden Berdasarkan Perilaku Pasien Hipertensi Dalam Pencegahan Komplikasi.}

Tabel 2.1 Distribusi Frekuensi Responden Berdasarkan Perilaku Pasien Hipertensi Dalam Pencegahan Komplikasi di Desa Samatan Wilayah Kerja Puskesmas Proppo Kabupaten Pamekasan Tahun 2017.

\begin{tabular}{cccc}
\hline No & Perilaku & (f) & $(\%)$ \\
\hline 1. & Kurang & 25 & 57 \\
2. & Cukup & 14 & 32 \\
3. & Baik & 5 & 11 \\
\hline & Total & 44 & 100 \\
\hline
\end{tabular}

Berdasarkan tabel 2.1 diketahui bahwa sebagian besar (57\%) responden perilaku pencegahan komplikasikurang sebanyak 25 responden dan sebagian kecil $(11 \%)$ responden perilaku baik pencegahan komplikasi sebanyak 5 responden.

\subsection{Perilaku Pasien Hipertensi Dalam Pencegahan Komplikasi}

Berdasarkan hasil penelitian tentang perilaku pasien hipertensi dalam pencegahan komplikasi di Desa Samatan Wilayah Kerja Puskesmas Proppo Pamekasan sebagian besar (57\%) kurang.

Perilaku adalah semua tindakan atau aktifitas seseorang yang terbentang luas, secara langsung ataupun tidak. (Notoatmodjo, 2007).Perilaku merupakan bagian menifestasi interaksi lingkungan dengan seseorang baik yang terlihat ataupun tidak (Purwanto, 2005).

Menurut teori Green pengetahuan, sikap, kepercayaan, tradisi, dan sebagainya dari orang atau masyarakat yang bersangkutan dapat menentukan perilaku seseorang. (Mobarak, 2006). resiko komplikasi hipertensi dapat dikurangi dengan pengendalian tekanan darah yang tepat. Sillent killer adalah sebutan untuk hipertensi karena tanpa gejala dan dapat menyebabkan kematian mendadak (Pasorong, 2007). Penurunan tekanan darah sistolik $5 \mathrm{mmhg} / 6 \mathrm{mmmhg}$ dengan obat anti hipertensi terbukti dapat menurunkan terjadi storke sebanyak 36\%- 42\% (Namsudin, 2000).

Pengobatan hipertensi dapat berupa pengobatan nonfarmakologik dan pengobatan farmakologik (Bakry dan Ariatyana, 1991). Modifikasi gaya hidup seperti olahraga, diet garam, menejemen stres, aktifitas fisik, menghindari alkohol dan rokok merupakan modifikasi pengobatan non farmakologi. Seseorang dengan hipertensi ringan melalui terapi nonfarmakologi dapat mengontrol tekanan darah dan dapat mengurangi kebutuhan atau dosis obat anti hiperetensi pada hipertensi berat (Bakry dan ariyatyana, 1991).

Salah satu faktor yang mempengaruhi perilaku pencegahan komplikasi hipertensi adalah jenis kelamin.Pada penelitian ini sebagian besar penderita hipertensi adalah laki- laki.Laki- laki cenderung memiliki sifat tidak perduli terhadap penyakitnya apalagi belum terlihat tanda dan gejala yang jelas dari komplikasi hipertensi.Laki- laki cenderung mengabaikan pengobatan rutin tidak melakukan kontrol secara teratur dan tetap mempertahanka kebiasaan- kebiasaan penyebab komplikasi dari hipertensi.Berbeda pada perempuan yang cenderung patuh untuk menjalankan pengobatan serta menghindari hal- hal penyebab terjadinya komplikasi dari hipertensi seperti menghindari makanan makanan berlemak, makanan asin, melakuakn kontrol secara rutin dan minum obat secara teratur.

Faktor berikutnya adalah faktor pendidikan.Pada penelitian ini sebagian besar responden adalah lulusan SMP. Dalam sistem pendidikan di indonesia lulusan SMP dikategorikan pada pendidikan dasar/ rendah. Seseorang dengan pendidikan rendah kemampuan menganalisanya cenderung sederhana hanya dengan mendengarkan dari orang lain tentang cara mencegah terjadinya komplikasi pada hipertensi seperti minum jamu akan dilakukan dan tidak teratur. Seseorang dengan pendidikan rendah memiliki kemampuan menangkap informasi dengan cara yang sederhana pula. Sehingga dapat dijelaskan perilaku pencegahan terhadap komplikasi dari hipertensi yang kurang dalam pendidikan ini disebabkan oleh tingkat pendidikan yang rendah sehingga kemampuan atau pengetahuannya ikut rendah juga. 
Faktor yang ketiga adalah faktor pekerjaan.Pada penelitain ini sebagian besar adalah sebagai petani.Seorang petani cenderung mengabaikan faktor penyebab terjadinya komplikasi hipertensi karena dituntut untuk bekerja bahkan sampai kelelahan. Petani juga cenderung mengabaikan aktifitas fisik yang lain seperti berolahraga (jalan kaki, berlari/ jogging). Petani beranggapan aktifitas fisik sperti olahraga sama seperti melakukan pekerjaan di sawah/ ladang. Aktifitas fisik seperti olahraga (jalan kaki, berlari, bersepeda) hanya dilakukan oleh orang yang pekerjaannya ringan seperti pekerja kantoran dan sebagainya.

\section{DAFTAR PUSTAKA}

Arikunto, S. (2004). Prosedur Penelitian Suatu Pendekatan Praktek. Jakarta: PT. Rineka Cipta

Azwar, Saifuddin. (2011). Sikap Manusia Teori dan Pengukurannya.Yogyakarta : Pustaka Pelajar

Bruner dan Suddarth.(2010). Keperawatan Medikal Bedah.Jakarta : EGC

Burner \& Suddarth, (2004).Buku Ajar Keperawatan Medikal Bedah Edisi 8 Volume 8.Jakarta : EGC

Dokter, (2007).Hipertensi (Tekanan Darah Tinggi). Jakarta: PT Raja Grafindo

Edwin, (2010).Hipertensi."http://arnoldkad ulli12081991. blogspot.com /2012/11/ proposal-hipertensi-pada-lansia.html" di unduh tanggal 8 februari 2015

Gordon. (2004). Stroke Panduan Latihan Lengkap.Jakarta: PT Raja Grafindo Persada

Mansjoer, Arief. (2005). Kapita Selekta Kedokteran. Jakarta: Media Aesculapius

Mansjoer, Arief. (2006). Kapita Selekta Kedokteran. Jakarta: Media Aesculapius

Marliani. (2007). Hipertensi(Tekanan Darah Tinggi). Jakarta : PT Rineka Cipta

Mahalul Azam. (2005). Klasifikasi Hipertensi. Jakarta: PT. Gramedia

Mubarak. (2006). Pengantar keperawatan komunitas. Jakarta PT. Gramedia

Ganong, William. (2008). Buku Ajar Fisiologi Kedokteran. Jakarta : EGC
Notoatmodjo. (2007). Definisi Sikap Manusia.http://lib.umpo.ac.id/gdl/files/di sk1/9/jkptumpo-gdl-khoirulmus-433-1abstrak,-1.pdf. Di unduh tanggal 19 Desember 2014

Notoatmodjo. (2008). Metodologi Penelitian Kesehatan. Jakarta : PT Rineka Cipta

Notoatmodjo. (2010). Pendidikan dan Perilaku Kesehatan. Jakarta : PT Rineka Cipta

Nursalam.(2006). Pendekatan Praktis Metodelogi Penelitian Ilmu Keperawatan. Jakarta: Sagung Seto

Nursalam. (2008). Konsep dan Penerapan Metodologi Penelitian Ilmu Keperawatan. Jakarta : Salemba Medika

Namsudin. ( 2000). Faktor resiko terjadi stroke. Jakarta : EGC

Palmer, Anna. (2007). Tekanan Darah Tinggi. Jakarta : Erlangga

Persagi.(2005). Penuntun Diit. Jakarta: PT Gramedia Pustaka Utama

Purwanto.(2005). Pengantar Perilaku Manusia. Jakarta. EGC

Riset Kesehatan Dasar (Riskesdas) 2013 Kementerian Kesehatan www.depkes.go.id/ Di Unduh Tanggal 20 Oktober 2017

Siti Kholifah. (2007) .Pandangan tentang perilaku. Jakarta. PT Renita Cipta

Suyono. (2004). Penyebab dan faktor-Faktor Hipertensi. Jakarta . PR Gramedia

Soeharto. (2004). Penyakit jantung koroner dan Serangan Jantung edisi kedua. Jakarta: PT Gramedia Pustaka Utama

Yunita Indah (2013). WHO Tahun 2013 Hipertensi Bukan untuk Ditakuti Jakarta:FMedia 